\title{
Vacina de DNA: aspectos gerais e sua aplicação na medicina humana e veterinária
}

\section{DNA vaccines: general concerns and its applications in human and veterinary medicine}

\author{
Flora Satiko Kano ${ }^{1}$; Odilon Vidotto ${ }^{2}$; Marilda Carlos Vidotto ${ }^{3 *}$
}

\section{Resumo}

\begin{abstract}
A vacinação com DNA é uma das mais promissoras técnicas de imunização contra uma variedade de patógenos e tumores, para os quais os métodos convencionais não tem sido eficientes. Vacinas de DNA são capazes de induzir resposta imune humoral e celular, tanto para resposta de linfócitos $\mathrm{CD}^{+}$quanto $\mathrm{CD}^{+}$, sem a necessidade de microrganismos vivos. Apesar do grande potencial de induzir imunidade protetora, a vacina de DNA nem sempre apresenta bons resultados. A imunidade depende de vários fatores como a seleção do gene alvo, construção do vetor de expressão, freqüência e via de administração da vacina, quantidade de DNA, localização do antígeno codificado pelo plasmídio e idade, saúde e espécies de animais vacinados. Esta revisão relata o desenvolvimento de algumas vacinas de DNA para doenças de interesse na medicina veterinária e humana.
\end{abstract}

Palavras-chave: Anaplasma marginale, vacina de DNA, bovinos, resposta humoral, resposta celular

\begin{abstract}
The vaccination with DNA is one of the most promising immunization techniques against a pathogens variety and tumors, for which the conventional methods have not been efficient. DNA vaccines are capable to induce immune humoral and cellular response, directed to lymphocytes CD4+ and CD8+, without the necessity of live microorganisms. In spite of the great potential of inducing protective immunity, the DNA vaccine not always has success. The immunity depends on several factors such as the selection of the target gene, construction of the expression vector, frequency and via of administration of the vaccine, amount of DNA, location of the antigen codified by the plasmid and age, health and species of vaccinated animals. This revision shows the development of some vaccines of DNA for diseases of interest in the veterinary and human medicine.
\end{abstract}

Key words: Anaplasma marginale, DNA vaccine, cattle, humoral response, cellular response

1 Médica Veterinária, Dra. Pelo Programa de Pós-Graduação em Ciência Animal

2 Professor Titular do Departamento de Medicina Veterinária Preventiva (DMVP), CCA, UEL

3 Professora Sênior do DMVP, CCA, UEL. E-mail: $\underline{\text { macarlos @uel.br }}$

* Autor para correspondência 


\section{Introdução}

A vacinação é a medida mais eficiente e menos dispendiosa para evitar doenças infecciosas. Apesar dos grandes benefícios das vacinas existentes, há ainda muitas doenças para as quais não existem vacinas. Recentemente tem ocorrido o ressurgimento de várias doenças, principalmente nos países em desenvolvimento.

Diversas estratégias têm sido utilizadas para o desenvolvimento de diferentes tipos de vacinas. As vacinas de primeira geração foram produzidas com microrganismos vivos e atenuados, como a vacina BCG contra a tuberculose, ou mortos e inativados como a vacina contra a Bordetella pertussis (BLOOM, 1989). Na última década, o grande avanço da biologia molecular permitiu a introdução de novas estratégias para a obtenção e a produção de antígenos e foram otimizadas novas maneiras de se administrar e apresentar esses antígenos para as células do sistema imune. Estas estratégias permitiram o desenvolvimento de vacinas mais seguras, eficazes e polivalentes. Entre estas estão as de subunidades, consideradas de segunda geração, constituídas de antígenos purificados e provenientes de fontes naturais ou sintéticas, e antígenos recombinantes. As vacinas gênicas ou de terceira geração surgiram com a introdução de genes ou fragmentos de genes, que codificam antígenos potencialmente imunogênicos, em vetores virais ou em DNA plasmidial (RODRIGUES JR et al., 2004).

A vacina de DNA foi descrita em 1990, quando o plasmídio contendo um gene repórter que codifica a â-galactosidase expressou a proteína após a inoculação direta no músculo de camundongos (WOLFF et al., 1990). Este estudo avaliou fatores que determinam a eficiência da transferência do gene e da imunogenicidade conferida pela inoculação do plasmídio. Posteriormente, a inoculação de DNA que codifica uma proteína imunogênica do vírus influenza conferiu imunidade protetora em camundongos (ULMER et al., 1993). A partir destes resultados, o entendimento sobre o mecanismo imunológico induzido por este tipo de vacina despertou interesse da comunidade científica.

Diversos trabalhos têm demonstrado a indução da imunidade protetora em camundongos pela imunização genética contra uma variedade de microrganismos como vírus (DAVIS; McCLUSKIE, 1999), bactérias (STRUGNELL et al., 1997) e protozoários (KALINNA, 1997), contra o câncer (LIU et al., 2004) e algumas doenças autoimunes (RAMSHAW et al., 1997). Na medicina humana, as pesquisas com vacinas de DNA têm sido direcionadas principalmente para a AIDS, malária e tuberculose (WANG et al., 1998, WANG et al., 2005; ZHANG et al., 2007). A utilização da vacinação por DNA na terapia contra tumores gerou resultados satisfatórios (LIU et al., 2004) e, recentemente, resultou no controle de crescimento de melanoma em estágio avançado (LIAO et al., 2006).

A administração de uma única dose de plasmídio pode proporcionar um amplo espectro de resposta imune, incluindo a ativação dos linfócitos $\mathrm{T} \mathrm{CD} 8^{+} \mathrm{e}$ linfócitos T CD4 ${ }^{+}$, os quais secretam citocinas e têm função reguladora na produção de anticorpos (KOWALCZYK; ERTL, 1999). O sucesso da imunização com DNA depende, principalmente, da natureza dos antígenos, da freqüência e via de administração, da concentração de DNA administrada, da localização celular do antígeno codificado pelo plasmídio (secretado, ligado à membrana ou citoplasmático), da idade e saúde do hospedeiro e da espécie dos animais vacinados (RAINCZUK et al., 2003; MOREL et al., 2004; ROBINSON, 1997; FYAN et al., 1993).

O material genético dos microrganismos é pouco estável na célula humana devido ao tamanho da molécula de DNA e à repulsão existente entre as cargas negativas da membrana da célula e do DNA. Quando o material genético não é transfectado à célula, rapidamente é degradado pelas nucleases (LEVY et al., 1996) e não haverá produção de anticorpos pela ausência da expressão protéica. Para facilitar a entrada do DNA na célula são utilizadas, 
em geral, partículas virais e lipossomas (PERKINS et al., 2005; BRIANE et al., 2002), mas há reações adversas. No caso das partículas virais o risco está na toxicidade dos vírus, que podem se integrar à célula (GLENTING; WESSELS, 2005). Melhorar a propagação pelas células é de grande importância para o desenvolvimento de vacinas de DNA, uma vez que a indução efetiva da imunidade tem requerido várias imunizações utilizando concentrações altas de plasmídios (MWANGI et al., 2005).

\section{Construção da Vacina de DNA}

A vacina é baseada na tecnologia do DNA recombinante que envolve a transferência de um determinado gene (transgene), que codifica uma proteína (imunógeno), dentro de um vetor de expressão para células eucarióticas (WAINE; McMANUS, 1995).

Durante a década de 90, diferentes vetores que expressam genes em células de mamíferos foram desenvolvidos, bem como novos métodos de transferência gênica direta (AZEVEDO et al., 1999). Um vetor ideal deve carrear grande capacidade genômica; ser de fácil produção; direcionar a resposta imune para tipos específicos de células; não permitir replicação autônoma do DNA; garantir uma expressão gênica por longo período; não ser tóxico; e não induzir reações de tolerância e auto-imune nos hospedeiros (GLENTING; WESSLES, 2005). Os vetores virais e plasmidiais são os mais utilizados na transferência gênica direta.

Os vetores virais são de fácil propagação entre as células, eficazes na ativação tanto da resposta imune humoral quanto celular e requerem muitas vezes, apenas uma aplicação (SEDEGAH et al., 1998). Entretanto, têm a desvantagem de serem derivados de patógenos; apresentarem risco de mutagênese insercional; inativação pelo sistema complemento; e serem contra-indicados para pessoas com imunodepressão. Portanto, os vetores virais são de interesse limitado para o propósito de imunização dependendo do gene em questão (GLENTING; WESSELS, 2005).

Um dos vetores utilizados nas vacinas de DNA é o plasmídio bacteriano, desenvolvido originalmente para expressão in vitro de proteínas em células de mamíferos (DAVIS; McCluskie, 1999). Os plasmídios apresentam maior segurança biológica, baixo custo, fácil produção, relativa estabilidade e capacidade genômica de 2 a 19 kilobases, que podem ser transferidos para as células musculares.

Os plasmídios utilizados como vacinas devem conter os seguintes elementos essenciais: i) um promotor de expressão para células de mamíferos; ii) sinal de poliadenilação (poliA) do transcrito (mRNA), iii) um marcador de seleção; iv) uma origem de replicação procariótica e v) sítio de múltipla clonagem onde é inserido o gene de interesse. Outras seqüências também são importantes como intron que aumenta a atividade do promotor, peptídeo sinal e sequiências de 6 nucleotídeos com função imunoestimulatória (GURUNATHAN et al., 2000; GLENTING; WESSELS, 2005), como mostra a Figura 1.

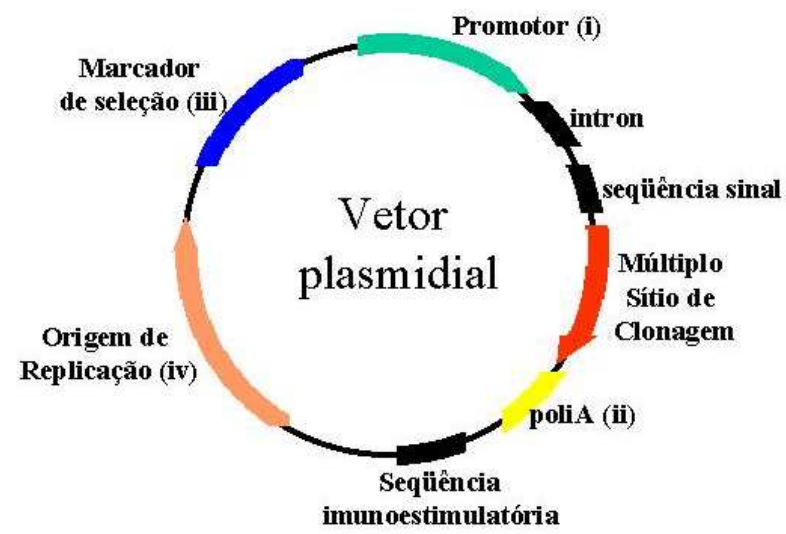

Figura 1. Representação esquemática das principais características genéticas de um vetor plasmidial utilizado na vacina de DNA. Fonte: Glenting e Wessels (2005)

Os plasmídios que possuem um forte promotor e que induzem a expressão em altos níveis da proteína em células eucarióticas, induzem uma melhor resposta imune (GARMONY et al., 2003). Os promotores de origem vírica como do citomegalovírus humano (hCMV) ou do vírus Simius 40 (SV40) 
induzem forte expressão protéica quando comparados com outros promotores (NORMAN et al., 1997, GARMONY et al., 2003), embora promotores de expressão alternativos como do vírus do sarcoma (RSV) possam ser utilizados. A expressão de um gene varia conforme o elemento regulatório. A expressão da glicoproteína $\mathrm{D}(\mathrm{gD})$ do herpesvírus bovino 1 (BoHV-1) sob o controle do promotor do citomegalovírus foi superior ao promotor originado do vírus do sarcoma humano. Entretanto, a característica do gene em questão pode influenciar na expressão protéica sob a regulação do mesmo promotor. A expressão da hemaglutinina do parainfluenzavírus bovino 3 e o gene OMLA do Actinobacillus pleuropneumoniae sob a regulação do promotor hCMV foi significativamente superior ao gene da gD do BoHV-1 (van DRUNEN LITTELvan den HURCK et al., 1999).

Posteriormente à região do promotor de expressão há uma região de múltiplos sítios de clonagem, seguida do gene da seqüência de poliadenilação (poliA), para proporcionar estabilidade à fita do RNA mensageiro (RNAm). A origem da seqüência de poliA mais utilizada é originada do gene do hormônio de crescimento bovino (BGH) ou do SV40 (XU, et al., 2001, GARMONY et al., 2003).

Os genes bacterianos de resistência aos antibióticos como a ampicilina e a kanamicina são os marcadores de seleção mais utilizados. Entretanto, a tendência é a substituição por vetores que não utilizam genes de resistência aos antimicrobianos devido ao risco do plasmídio transformar a microbiota do hospedeiro e disseminar a resistência aos antimicrobianos (GLENTING; WESSELS, 2005). A origem de replicação bacteriana é derivada da Escherichia coli ColE1 que está presente nos plasmídios de clonagem da série pUC. Esta origem de replicação proporciona um elevado número de cópias de plasmídios, a qual permite a obtenção de grande quantidade de plasmídios purificados (AZEVEDO et al., 1999, GURUNATHAN et al., 2000, GARMONY et al., 2003).
Vantagens e os Potenciais Problemas das Vacinas de DNA

As vacinas de DNA oferecem uma série de vantagens quando comparadas às vacinas clássicas, em termos econômicos e técnicos. O custo de produção das vacinas gênicas em larga escala é consideravelmente menor ao custo de produção das vacinas compostas de fração subcelular, proteínas recombinantes e peptídeos sintéticos (WHALEN, 1996, ROBINSON, 1997). O controle de qualidade é mais fácil, a comercialização não necessita de uma rede de refrigeração, pois estas vacinas são estáveis à temperatura ambiente e podem ser liofilizadas (WAINE; McMANUS, 1995). Estes fatores facilitam o transporte, a distribuição e o estabelecimento de amplos programas de imunizações em regiões de difícil acesso, o que seria interessante para a realidade brasileira e de outros países em desenvolvimento (AZEVEDO et al., 1999, GLENTING; WESSLES, 2005).

A principal vantagem da vacina de DNA é que assim como as vacinas atenuadas ela induz a produção de anticorpos e de resposta imune celular, tanto linfócitos $\mathrm{T}$ auxiliares $\left(\mathrm{CD}^{+}\right)$quanto $\mathrm{T}$ citotóxico $\left(\mathrm{CD}^{+}\right)$(van TIENHOVEN et al., 2001, NAGATA et al., 2004). Adicionalmente, as vacinas gênicas não são afetadas pelos anticorpos maternos, não apresentam risco de reversão da atenuação e podem ser produzidas contra agentes infecciosos de difícil cultivo e atenuação. A vacina pode ainda ser co-administrada para multiagentes ou multiepitopos de um determinado agente infeccioso (HAN et al., 1999, DOOLAN; HOFFMAN, 1997).

No caso de indivíduos imunocomprometidos, um grupo com alto risco de desenvolver uma doença, a vacina de DNA seria interessante, pois uma vacina comercial como por exemplo contra a tuberculose (BCG) é contra-indicada (WHALEN, 1996). Em crianças e idosos, cujo sistema imunológico se apresenta imaturo ou deficiente, a avaliação da vacina de DNA não apresentou os riscos proporcionados pelas vacinas vivas atenuadas (SIEGRIST, 1997). 
A tecnologia do DNA recombinante permite modificações nas seqüências gênicas, objetivando a melhoria na resposta imunológica do hospedeiro, tais como incorporações de seqüências imunoestimulatórias (ISS), seqüências de genes que codificam interleucinas e genes virais que codificam proteínas que melhoram a propagação em células (RAINCZUK et al., 2003; ZHENG et al., 2005).

Os riscos que podem ser gerados com vacinas de DNA, como a integração do plasmídio ao genoma hospedeiro, gerando mutagênese pela ativação de protoncogenes ou pela inativação de genes supressores de tumor, estão sendo avaliados. Estudos têm mostrado baixa probabilidade de ocorrer integração do plasmídio. Três diferentes vacinas de DNA contendo genes virais foram avaliadas em camundongos, e se a integração tivesse ocorrido, a frequiência seria de oito integrações do DNA por células diplóides. Isto seria três vezes abaixo da frequiência de mutação espontânea. Contudo, ensaios de integração são necessários para todos os DNA plasmidiais que serão usados em vacinas para uso clínico. Outros riscos incluem a indução de tolerância, devido à apresentação do antígeno em longo prazo, ou reações auto-imunes devido à indução de anticorpos anti-DNA. Os níveis destes anticorpos têm aumentado de 20-30\% em seres humanos, mas não induzem qualquer doença com os títulos apresentados, ao contrário do aumento de 100-1000 vezes detectado em pacientes com doenças autoimunes (HENKE, 2002).

\section{Mecanismo de Ação e Indução da Resposta Imune}

Inicialmente os mecanismos de processamento e apresentação de antígenos em células musculares foram questionados, uma vez que estas células não expressam antígenos associados ao complexo principal de histocompatibilidade de classe II (MHC II), moléculas co-estimuladoras B-7 e ao antígeno-3 associado à função do leucócito (LFA-3), presentes em células especializadas em apresentação de antígenos (BOYLE et al., 1998; LATOUCHE \& SADELAIN, 2000). As células musculares, provavelmente, liberam antígenos localmente, os quais são processados pelas células apresentadoras de antígenos (APCs), tais como as células dendríticas e as de Langerhans (RAZ et al., 1993, WOLFF et al., 1990, MUMPER \& LEDEBUR, 2001).

No mecanismo proposto (Figura 2), após a inoculação intramuscular, o DNA é incorporado às células musculares (miócitos) e/ou células APC. Os DNAs que forem endocitados pelas células no sítio de inoculação permanecem no núcleo celular sem ocorrer incorporação ao genoma da célula hospedeira. As vias metabólicas da célula hospedeira são utilizadas para os processos de transcrição do DNA inoculado e, em seguida, o RNA mensageiro é traduzido para que ocorra a síntese do antígeno protéico relacionado ao agente infeccioso. Os antígenos expressos endogenamente são processados pelas APCs e os fragmentos resultantes complexados com moléculas de classe I que são codificadas por genes do complexo de histocompatibilidade (MHC I). Em seguida, estes peptídeos são apresentados na superfície celular para o reconhecimento e ativação específica de linfócitos T CD8 citotóxicos. Alguns dos antígenos produzidos pelas células musculares são secretados para o espaço extracelular, onde podem tanto estimular linfócitos B a produzir anticorpos específicos como ser endocitados por outras células apresentadoras de antígenos. No processo de endocitose os antígenos passam do compartimento extracelular para o interior das células APC e, por este motivo, são considerados antígenos exógenos e assim processados em compartimentos celulares diferentes daqueles realizados quando o antígeno é originado dentro da célula. Os fragmentos de antígenos exógenos são complexados com moléculas da classe II e apresentados na superfície das células apresentadoras para o reconhecimento e ativação de linfócitos T CD4 auxiliares. As vacinas de DNA são, portanto, capazes de induzir ambos os tipos de imunidade protetora, humoral e celular, com a estimulação de linfócitos $\mathrm{T} \mathrm{CD} 4^{+}$e $\mathrm{T} \mathrm{CD} 8^{+}$, sem 
alguns dos possíveis riscos associados às vacinas com organismos vivos (HENKE, 2002).

Após o processamento e apresentação de antígenos pelas APCs são produzidas citocinas, como a IL-12, que estimula a diferenciação das células $\mathrm{T}$ virgens em Th1 efetoras (SIN et al., 1999). Por sua vez, as células Th1 produzem citocinas como o IFN-g que pode atuar na célula alvo que carreia o transgene (OLIVEIRA et al., 1998; NAGATA et al., 2004) e melhorar a expressão de moléculas de MHC classe II pelas células apresentadoras de antígenos, facilitando a apresentação do antígeno e a ativação da célula $\mathrm{T}$.

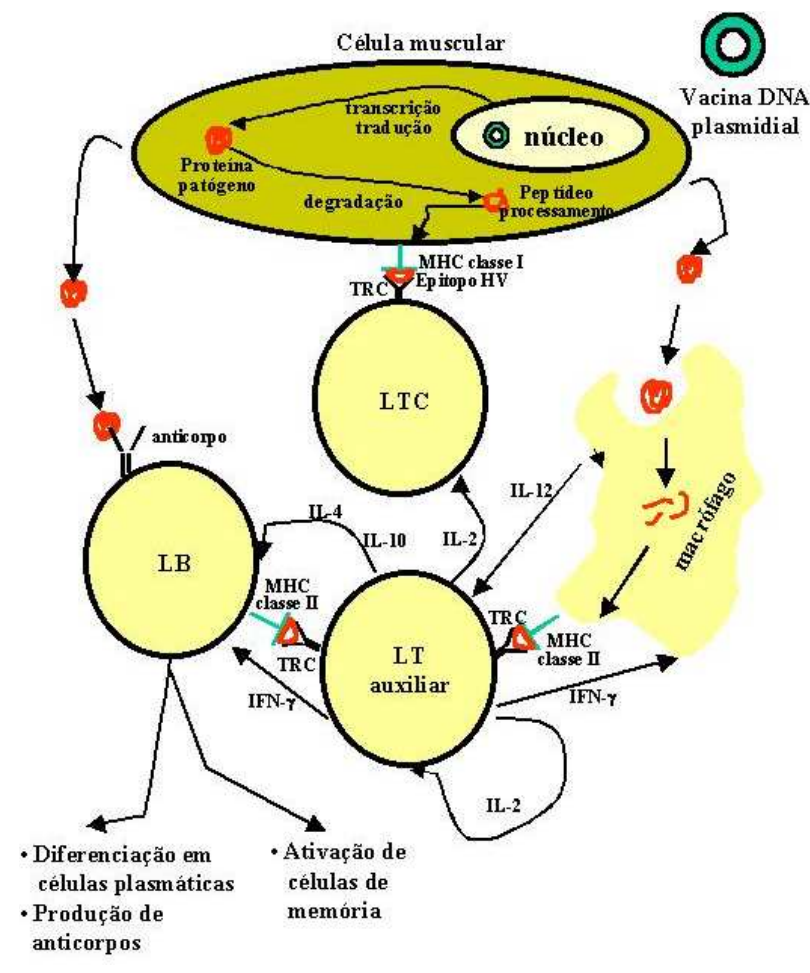

Figura 2. Hipótese mais aceita do mecanismo de ação da vacina de DNA utilizando DNA plasmidial. Após a imunização com vacina de DNA o antígeno pode ser apresentado às células $\mathrm{T}$ pelas células apresentadoras de antígenos (APCs) ou células somáticas (células musculares) transfectadas com o DNA plasmidial expressando antígenos. Estas células, particularmente as células somáticas, podem liberar antígeno para outra APC, pela secreção ou por apoptose das células transfectadas. Estas APCs podem então, apresentar antígeno para células T CD4+ e CD8+. Fonte: adaptado http:// www.brookscole.com
No plasmídio contendo o transgene, pode-se clonar os genes que codificam os componentes estimuladores da resposta imune (IL-2, IL-12 e IFNg) ou mesmo co-administrar os plasmídios recombinantes que codificam estas citocinas. Isto auxilia no processo de reconhecimento antigênico entre as APCs e os linfócitos (RAZ et al., 1993; XIANG et al., 1997).

A imunidade adquirida pela vacina de DNA persiste por longo período de tempo devido à constante produção endógena do antígeno pela célula hospedeira e à capacidade destes antígenos estimularem linfócitos de memória imunológica (SNADEEP et al., 1996).

A imunidade humoral é responsável por uma significativa resposta preventiva nas infecções e a IgG2a tem sido o isotipo predominantemente induzido pelas vacinas de DNA plasmidial (VERCAMMEN et al., 2000; OÑATE et al., 2003). O IFN-g produzido pelo linfócito Th1 é uma importante citocina moduladora de células B para a secreção de $\operatorname{IgG} 2 \mathrm{a}$ antígeno específico. Em muitas infecções por microrganismos intracelulares em camundongos a resposta humoral é caracterizada pelo predomínio dessa imunoglobulina (COUTELIER et al., 1991, NAGATA et al., 2004). Por outro lado, a produção de imunoglobulinas IgG1 e IgE específicas, dependem, em parte, da presença da interleucina 4 (IL-4) produzida pela subpopulação de linfócitos T auxiliares (Th2) (SNAPPER et al., 1988).

Fatores como dose de antígeno, tipo de patógeno, a espécie animal, via de infecção ou imunização, formulação da vacina, e a forma do antígeno (solúvel ou associado) influenciam no desenvolvimento do tipo de resposta imune (FYAN et al. 1993, MOREL et al. 2004, JIN et al., 2004, NAGATA et al., 2004).

\section{Adjuvantes para Vacina de DNA e seu Papel na Imunidade Inata \\ Nas vacinas de subunidade, tais como as vacinas constituídas por proteínas recombinantes,}


freqüentemente há necessidade da utilização de adjuvantes para aumentar a imunogenicidade do antígeno (ULMER et al., 2006). Os adjuvantes, em sua maioria, são moléculas derivadas de patógenos como o lipídeo monofosforil; derivados de saponina QS21; adjuvantes químicos como o levamisol e a bupivacaína; e seqüências $\mathrm{CpG}$ que ativam células do sistema imune inato. Uma vez ativada essas células modulam e direcionam para a resposta imune adquirida ou adaptativa (SINGH \& O'HAGAN, 2002; LIMA et al., 2004, JIN et al., 2004).

As sequiências $\mathrm{CpG}$ imunoestimulatórias são originadas de DNA bacteriano, não metiladas com dinucleotídeos $\mathrm{CpG}$ flanqueados por purinas e pirimidinas, diferentemente do DNA de vertebrados. Estas seqüências podem estar presentes em plasmídios bacterianos ou ser associadas ao plasmídio recombinante para aumentar a efetividade da vacina. O sistema imune de vertebrados detecta a presença do DNA CpG estranho pela ligação com o receptor Toll-like (TLRs) das células APCs e liberação de citocinas, os quais estimulam a resposta imune adquirida (SINGH; O'HAGAN, 2002). O efeito adjuvante das sequências $\mathrm{CpG}$ é influenciado pela presença do antígeno e liberação do DNA (SINGH et al., 2000; COBAN et al., 2005). Existem controvérsias sobre o efeito adjuvante das seqüências CpG porque nem sempre a incorporação em plasmídio demonstrou melhora na resposta imune. Entretanto, há resultados que demonstram o aumento da imunogenicidade da vacina (ULMER et al., 2006).

Seqüências que codificam citocinas, quimiocinas e moléculas co-estimulantes podem ser incorporadas ou co-administradas aos plasmídios recombinantes para modular a resposta imune (ULMER et al., 2006). As citocinas avaliadas como adjuvantes incluem IL1, IL-2, IL-12, IFN-ã e o fator estimulante de macrófago granulocítico (GM-CSF) (PASQUINI et al., 1997). Contudo, todas estas moléculas exibem toxicidade relacionada à dose. Genes que codificam citocinas, incluindo IL-2, IL-4, IFN-ã foram testados para avaliar a habilidade de ampliação da resposta imune em camundongos (DUFOUR, 2001). A incorporação do gene do GM-CSF de suíno na vacina de DNA contra a Doença de Aujeszky (DA) demonstrou aumento da proteção clínica de suínos, proporcionada pelo aumento da atividade de célula T (SOMASUNDARAM et al., 1999). A adição do gene que codifica o IFN-ã à vacina de DNA contra vírus da imunodeficiência felina (FIV) também aumentou a proteção clínica revelando um decréscimo da carga viral após a infecção (HOSIE et al., 1999). Entretanto, a incorporação do gene do IFN-ã suíno reduziu a proteção clínica contra a DA (SOMASUNDARAM et al., 1999).

Outra citocina particularmente interessante, a IL15, semelhante a IL-2, tem importante participação na proliferação das células $\mathrm{T}$ de memória $\mathrm{CD} 8^{+}$ (KUTZLER et al., 2005). Porém, o DNA plasmidial que codifica a IL-15 tem o seu uso limitado devido sua regulação complexa, que resulta na baixa expressão da citocina in situ. Contudo, em recente estudo, uma forma do plasmídio IL-15 aumentou a proliferação, longevidade e função efetora das células T CD8+, quando medida pelo aumento da imunogenicidade e eficácia protetora da vacina de DNA para influenza e HIV em camundongos (KUTZLER et al., 2005).

Genes de receptores estimulatórios (NKG2D) encontrado nas células natural killer (NK) e nas células T citotóxica também podem ser incorporados ao DNA plasmidial. Esta incorporação demonstrou aumento da eficácia das vacinas de DNA contra o câncer em camundongos (ZHOU et al., 2005).

\section{Vias de Administração da Vacina de DNA}

A administração da vacina de DNA utilizando a inoculação direta do plasmídio pelas vias intratraqueal, intravenosa, intrabursal, intraorbital, intradérmica, intramuscular, oral, subcutânea e via mucosa demonstraram sucesso na indução da resposta imune em todas as vias testadas (FYNAN et al., 1993; ULMER et al., 1997; UCHIJIMA et al., 1998; REN et al., 2002; YOSHIDA et al., 2000; CONG et al., 2005, LI, et al., 2006). Entretanto, algumas vias 
proporcionaram maior ou menor nível de expressão de antígenos influenciando diretamente na imunogenicidade da vacina.

Os níveis de expressão dos antígenos obtidos pelas diferentes vias de administração parecem estar relacionados com a quantidade de células transfectadas obtidas após administração dos plasmídios. A via intramuscular (i.m.) e a intradérmica (i.d.) liberam o DNA plasmidial no meio extracelular, localização pela qual, a maioria do DNA é rapidamente degradada pelas nucleases (LEVY et al., 1996). Diferentemente, o sistema gene gun libera o DNA dentro das células amenizando a perda inicial do DNA. Nos trabalhos iniciais avaliando as vias de administração da vacina foi necessária uma concentração de DNA pela via intramuscular 100 vezes maior que o sistema gene gun para proporcionar uma resposta imune equivalente (ROBINSON, 1997).

O sistema gene gun utilizado para vacinas de DNA foi avaliado em bovinos, eqüinos, suínos, caninos e em aves (FYAN et al., 1993; MACKLIN et al., 1998; VANROMPAY et al., 1999). Em galinhas, o gene gun foi o sistema mais eficiente para a liberação da vacina de DNA para influenza (FYNAN et al., 1993). Em perus, a combinação das vias i.m. e intranasal induziu equivalente proteção contra a Clamydia psittaci comparada à liberação obtida pelo gene gun (VANROMPAY et al., 1999). Por outro lado, em suínos as imunizações pela via i.m. da vacina de DNA contra peste suína clássica induziram mais altos títulos de anticorpos do que pelo sistema gene gun (ANDREW et al., 2000). Assim, a eficácia da vacina de DNA varia com vários fatores que podem influenciar nestas vias de administração, como vetor, adsorção às partículas, a espécie animal e o patógeno.

O tipo de vetor utilizado nas imunizações com DNA na geração da resposta imune protetora adquirida foi relatado. A imunização de camundongos com os vetores VR1020 (expressa proteína secretória) e o vetor que expressa a proteína quimotática associada ao monócito 3 (MCP-3), administradas pela via i.d., induziram altos títulos de anticorpos. Contudo apenas o vetor MCP-3 apresentou resposta imune protetora pela imunização com DNA plasmidial. A proteção utilizando o vetor VR1020 foi observada apenas após o reforço da dose com proteínas recombinantes (RAINCZUK et al., 2003).

A localização celular da proteína, influenciada pela via, é importante no tipo de resposta imune gerada (LEWIS et al., 1999, MOREL et al., 2004). Geralmente, a imunização pela via i.m. induz preferencialmente a resposta Th1, enquanto que o sistema gene gun administrado na derme, estimula a reposta Th2 ou uma resposta balanceada Th1/Th2, caracterizando a resposta imune humoral (NAFTZGER et al., 1996; WEBER et al., 1998). Entretanto, a imunização de camundongos por sistema gene gun com plasmídios que codificam proteínas (ovoalbumina) citoplasmáticas e transmembrana induziram forte resposta imune Th1 e CD8 $8^{+}$(MOREL et al., 2004). O predomínio da resposta Th1, determinada pelos títulos de IgG2a (razão de IgG2a/ IgG1 =3), também foi demonstrado em camundongos imunizados com o plasmídio contendo o gene da proteína do envelope do vírus da encefalite japonesa. Por outro lado, quando os plasmídios foram administrados revestidos com micropartículas cationnicas foram observadas tanto a resposta Th1 quanto Th2 e os títulos de anticorpos IgG2a e IgG1 foram similares (razão of IgG2a/IgG1 =1.13) (KAUR et al., 2004).

\section{Recentes Avanços para Aumentar a} Imunogenicidade da Vacina de DNA

A vacina de DNA tem apresentado baixa imunogenicidade em primatas, entretanto duas vacinas foram recentemente licenciadas para animais, uma contra o vírus da febre do Nilo do Ocidente em eqüinos e a outra contra vírus da necrose hematopoiética infeciosa em salmão (ULMER et al., 2006). Provavelmente, a falha da vacina de DNA em induzir forte resposta imune em seres humanos é 
a baixa produção de antígenos, a liberação celular do DNA plasmidial e a estimulação ineficiente do sistema imune inato ineficiente. Os esforços para aumentar estes aspectos da vacina de DNA aumentaram sua eficácia em animais (ULMER et al., 2006).

Alterações nos vetores têm sido realizadas para melhorar a potência da vacina como alteração no vetor para aumentar a eficiência do promotor; utilização de sequiência líder alternativa e substituição de códons de mamíferos pelos usados por patógenos. Esta última alteração, a construção de vetores com otimização de códons, é para evitar as limitações do conteúdo celular de tRNA com códons virais e bacterianos, uma vez que os requerimentos para a tradução do mRNA do patógeno são diferentes dos das células de mamíferos. A otimização do códon resultou no aumento da expressão do antígeno gp120 do HIV, contribuindo para uma melhor disponibilidade de tRNA e maior estabilidade do mRNA específico (WANG et al., 2005).

A captação do DNA plasmidial pelas células após a injeção é ineficiente. Somente uma pequena proporção do material injetado é internalizada pelas células que resulta em sucesso na transfecção, isto é, produção de antígeno pelas células do animal vacinado. Entretanto, duas estratégias têm sido utilizadas para aumentar a potência da vacina: i) liberação física para alcançar altos níveis de antígenos e ii) formulação com micropartículas para células alvo apresentadoras de antígenos (APCs) (ULMER et al., 2006).

Uma efetiva tecnologia de liberação física do plasmídio usa a eletroporação (EP) in situ para a liberação do vetor diretamente dentro das células. Esta tecnologia foi adaptada para uso em animais vivos, pelo qual um campo elétrico é criado nos tecidos perto do sítio de inoculação da vacina. A EP aumenta substancialmente a produção de antígenos e a resposta da célula $\mathrm{T}$ em primatas não-humanos, produzindo altos níveis de célula $\mathrm{T} \mathrm{CD} 8{ }^{+}$como 5\% do total de célula T (OTTEN et al., 2006). Este nível de imunogenicidade em primatas é usualmente obtido somente pelo uso de vetores virais vivos, como adenovírus recombinante (ULMER et al., 2006). Outra recente tecnologia de liberação física do plasmídio usa tattooing com o objetivo de administrar o DNA nas células da pele (BINS et al., 2005). Esta técnica, a qual é similar à vacinação efetiva com a varíola, parece diminuir o tempo requerido para a indução de resposta imune potente e protetora. Isto deve estar relacionado com a rápida produção do antígeno após a vacinação.

Uma segunda estratégia para liberação da vacina de DNA envolve a tecnologia baseada em micropartículas para as APCs alvo. A eficácia das vacinas de DNA aumenta se o material genético for revestido por microesferas biodegradáveis que o protegem e liberam de forma gradual nas células do organismo vacinado. Partículas de 1-3 $\mu$ m de diâmetro são rapidamente fagocitadas pelos macrófagos e células dentríticas (DCs). Duas distintas formulações, baseadas em polímeros (ácido láctico e ácido glicólico PLG) e lipídio catiônico foram relatadas recentemente. Estas formulações mostraram-se efetivas para a liberação da vacina de DNA para o HIV em modelos primatas (OTTEN et al., 2005) e antrax em coelhos (HERMANSON et al., 2004). Em ambos os casos, a interação de moléculas de DNA plasmidial carregadas negativamente com a formulação carregada positivamente é crucial para liberação do DNA dentro das APCs, resultando no aumento da apresentação do antígeno para o sistema imune. Os polímeros PLG são biocompatíveis com as membranas celulares, pois são produzidos pelo organismo humano e as microesferas não são tóxicas e liberam o material genético de forma gradual, o que garante a produção contínua de antígenos e anticorpos. A quantidade de cada substância nas microesferas determina o ritmo da liberação do DNA. (RODRIGUES JR et al., 2004).

Uma das razões pela quais as vacinas de DNA são menos potentes que as vacinas vivas atenuadas é que o DNA não se distribui de maneira uniforme entre as células inicialmente transfectadas, enquanto 
o número das células infectadas pelo microrganismo atenuado aumenta quando este se replica. Esforços têm sido realizados para aumentar o trânsito intracelular do antígeno, explorando a capacidade de espalhamento célula-célula da proteína VP22 do herpesvírus humano tipo1 ou do BoHV-1. Vários grupos têm demonstrado que construções de DNA, que codificam proteínas de fusão da VP22 ligada a antígenos, aumentam a resposta imune em camundongos (KIM et al., 2004; PERKINS et al., 2005) e bovinos (ZHENG et al., 2005). Contudo, há controvérsia nesses resultados. Alguns grupos mostraram que proteínas fusionadas com VP22 aumentam o espalhamento intracelular quando avaliado in vitro (MWANGI et al., 2005), ou pelo número de células dendríticas transfectadas em nódulos linfáticos (KIM et al., 2004). A incorporação do gene da VP22 proteína de fusão do BoHV-1 demonstrou aumento da aquisição do DNA plasmidial pelas células dendríticas e macrófagos, o qual, melhorou a resposta celular de linfócitos $\mathrm{T}$ auxiliar $\left(\mathrm{CD}^{+}\right)$com quantidades menores de DNA plasmidial (MWANGI et al., 2005). Contudo, um estudo não constatou a diferença na distribuição das proteínas de fusão-VP22 e que o antígeno isoladamente, obtido da transfecção do respectivo plasmídio dentro das células de mamíferos, aumentou a resposta imune in vivo (PERKINS et al., 2005). Mais estudos são necessários para elucidar o modo de ação desta estratégia.

\section{Vacina de DNA na Medicina Humana $e$ Veterinária}

Vacinas de DNA mostraram serem efetivas para várias doenças causadas por vírus, bactérias, protozoários e também para tumores. Conseqüentemente, esse tipo de vacina contribui para o controle de doenças infecciosas, parasitárias e na terapia oncogênica em medicina humana e veterinária.

As vacinas de DNA que codificam antígenos virais têm sido as mais investigadas e aquelas específicas para o HIV foram as primeiras vacinas contra doenças infecciosas a serem avaliadas em seres humanos (MacGREGOR et al., 1998). O HIV possui uma glicoproteína do envelope altamente variável e a maioria dos anticorpos gerados são muito específicos para essa proteína. Em contraste, a resposta celular pode ser direcionada contra epítopos que são derivados de várias proteínas, incluindo aquelas altamente conservadas entre diferentes estirpes virais. As atuais pesquisas têm focado o uso do DNA na primo-vacinação, seguida de um reforço heterólogo utilizando um vetor viral, pois a primovacinação com DNA demonstrou ser mais potente em primatas não-humanos (ULMER et al., 2006).

A vacina de DNA contra o HIV induziu resposta imune mediada por células (CMI) em camundongos, mas estimulou fraca produção de IFN-g pelas células $\mathrm{T}$ em primata não-humano e também em seres humanos. A análise de esplenócitos de camundongos BALB/c imunizados com uma única dose de vacina de DNA demonstrou duas populações de linfócitos T, o CD4+ e CD8+, que foram específicos para os antígenos do HIV. Os linfócitos CD8+ produtores e não-produtores de IFN-g foram detectados nos estágios inicial e intermediário após a imunização (ARRODE et al., 2007).

Vacinas de DNA para a hepatite B foram analisadas em suínos e primatas não-humano. Três doses da vacina induziram títulos de anticorpos protetores nos animais e a resposta em suínos foi comparável aos títulos induzidos com três doses da vacina comercial com proteínas recombinantes (FULLER at al., 2006). Em humanos, esta vacina constituída do antígeno sAg induziu resposta celular $\mathrm{CD}^{+}{ }^{+}$CD4 ${ }^{+}$significativa em $100 \%$ dos indivíduos (ROY et al. 2000).

Vacinas de DNA para os vírus da influenza (MACKLIN et al., 1998) e do sarampo também foram analisadas em suínos e macacos por gene gun, mas induziram produção de anticorpos duas a dez vezes menor do que as respectivas vacinas virais com vírus inativado. Contudo, estas vacinas de DNA ainda mostraram proteção significativa contra a infecção, demonstrando que, embora a vacina de 
DNA induza imunogenicidade mais baixa, quando comparado com as vacinas existentes, os níveis são ainda suficientes para proporcionar proteção (FULLER et al., 2006).

A vacina de DNA para a raiva administrada em macacos por gene gun, similarmente à vacina para o vírus da influenza, induziu comparável produção de anticorpos e proteção contra infecção letal com vírus da raiva, como na vacina produzida em células diplóides (LODMELL et al., 1998).

Entre as vacinas de DNA para infecções bacterianas, a vacina para o controle da tuberculose humana e bovina foi uma das primeiras vacinas estudadas. O antígeno MPB83 do Mycobacterium bovis demonstrou boa proteção em camundongos imunizados quando desafiados com cepas virulentas e estimulou resposta mista de IgG1 e IgG2a. Posteriormente, a imunogenicidade da vacina foi avaliada em bovinos que apresentaram alta taxa de resposta proliferativa ao antígeno MPB83 (CHAMBERS et al., 2000). A utilização do gene da proteína hsp65 do M. tuberculosis foi avaliada na imunização genética de camundongos BALB/c pela via intramuscular nas formas "nua" (naked) e sistema gene gun. A administração do plasmídio pelo sistema gene gun induziu resposta imune com doses 100 vezes menor do que as requeridas pela imunização i.m. Contudo, a imunização i.m. protegeu os camundongos e a imunização pelo sistema gene gun induziu a resposta Th2 com altos títulos de IL-4 e IL-10, mas não protegeu os camundongos contra o desafio com cepas virulentas (LIMA et al., 2001).

A associação do gene da hsp65 de M. tuberculosis à expressão da IL-12 induzida pelo vírus hemaglutinante do Japão (HVJ) incorporada ao lipossoma (HSP65+IL-12/HVJ) demonstrou melhor eficácia na proteção de camundongos e de cobaios quando comparados com a vacina BCG. Em macacos Cynomolgus, esta formulação apresentou eficácia na proteção relacionada à mortalidade, peso corporal, achados radiográficos e imunogenicidade. A combinação da vacina HSP65+IL-12/HVJ e BCG demonstrou efeito sinérgico nos macacos infectados com tuberculose, determinando $100 \%$ de sobrevivência. Estes dados indicam um novo modelo de vacina de DNA contra o M. tuberculosis que pode ser utilizado para os ensaios clínicos fase inicial em humanos (OKADA et al., 2007).

A administração inicial do DNA plasmidial contendo o gene da proteína 58 (Ag85B) do M. tuberculosis demonstrou proteção contra a infecção pelo M. tuberculosis e associou-se a participação de linfócitos $\mathrm{CD} 4+$ específicos ao $\mathrm{Ag} 58 \mathrm{~B}$ na produção de IFN-g e de controle do crescimento intramacrofágico do M. tuberculosis. Surpreendentemente, essa proteção foi eliminada após o reforço vacinal com a proteína recombinante (rAg58B). Segundo os autores, a perda da proteção foi relacionada com a excessiva proliferação de linfócitos CD4+e à produção de IFN-g em resposta à proteína $\mathrm{Ag} 58 \mathrm{~B}$. Estudos realizados no Brasil, utilizando a proteína P58 do Mycobacterium na construção de uma vacina de DNA, identificaram uma atividade anti-cancerígena importante deste gene em pacientes com melanoma, um dos mais graves tumores de pele. Após o tratamento houve a remissão do tumor em dois pacientes com diagnóstico de melanoma (RODRIGUES JR et al., 2004).

Para o controle da brucelose, uma vacina de DNA contendo o gene da enzima superóxido desmutase (SOD) de Brucella abortus foi construída com o objetivo de diminuir os riscos de contaminação dos manipuladores com a utilização da vacina viva atenuada (cepas B19 e RB51) (VELIKOVSKY et al., 2002). Camundongos BALB/c receberam três doses por via i.m. e apresentaram altos títulos de anticorpos com predomínio da IgG2a e proliferação de linfócitos com produção de IFN-g. O grau de proteção dos camundongos desafiados com $10^{4}$ UFC da cepa B. abortus 2308, após cinco semanas da última imunização, foi similar aos animais vacinados com a cepa vacinal RB51 (OÑATE et al., 2003). Posteriormente, camundongos foram imunizados com esta mesma construção pela via intraesplênica para induzir resposta celular. Até o final do experimento 
não foram detectados anticorpos específicos para a SOD. Na estimulação de esplenócitos, foi detectada secreção de IFN-g, mas não de IL-4 e apenas a população de $\mathrm{CD} 8+$ apresentou atividade citotóxica. Após quatro semanas da imunização, camundongos foram desafiados intraperitonialmente com cepas virulentas de B. abortus, mostrando proteção superior à via i.m. (MUÑOZ-MONTESINE et al., 2004).

Para o Staphylococcus aureus a vacina de DNA contendo um gene importante da adesina da bactéria (ClfA) induziu a produção de anticorpos específicos e resposta celular em vacas em lactação. A inclusão de adjuvantes com os plasmídios diminuiu a variabilidade da resposta entre os animais e a resposta de anticorpos foi altamente direcionada para IgG2 no soro e leite, ocorrendo uma fraca resposta de IgG1 específica para ClfA sem adjuvante. A estratégia de se utilizar um reforço com proteínas induziu anticorpos que aumentaram a fagocitose e diminuíram a adesão da bactéria. Os resultados sugerem que a injeção intramuscular do plasmídio codificando ClfA de S. aureus gera resposta Th1 em vacas leiteiras e a estratégia de vacinação combinando adjuvantes moleculares e reforço com adesinas será um importante componente da vacina contra a mastite bovina ocasionada pelo $S$. aureus (NOUR EL-DIN, et al., 2006).

A vacina de DNA contra a leptospirose que codifica uma proteína associada à hemólise (Hap1) foi avaliada em gerbil. Após três semanas da imunização os animais foram protegidos contra o desafio com a Leptospira interrogans patogênica (BRANGER et al., 2005).

Genes que codificam proteínas do Plasmodium falciparum, agente da malária, foram relatados como seguros e imunogênicos para seres humanos (WANG et al., 1998; EPSTEIN et al., 2004; WANG et al., 2005). Estudos com diferentes proteínas do Plasmodium spp estão sendo desenvolvidos na tentativa de caracterizar e eleger os antígenos mais imunogênicos e protetores para a doença. Tentativas de utilização de diversos genes para mimetizar os antígenos do protozoário mostraram que alguns genes interferem negativamente, inibindo a expressão de um outro antígeno (SEDEGAH et al., 2004).

A imunização de camundongos com os plasmídios contendo os genes que codificam as proteínas GRA1, GRA7 e ROP2 de Toxoplasma gondii induziu imunidade protetora parcial contra desafios letais. $\mathrm{Na}$ linhagem de camundongos $\mathrm{C} 3 \mathrm{H}$ a razão $\mathrm{Ig} 2 \mathrm{a} / \mathrm{IgG} 1$ foi maior quando comparada às linhagens $B A L B / c$ e C57BL/6 de camundongos. Coincidentemente, a porcentagem de proteção contra desafios letais com cistos de T. gondii foi maior em camundongos da linhagem C3H (VERCAMMEN et al., 2000).

Para Taenia solium a imunização com DNA plasmidial contendo o gene do antígeno B de Cisticercus cellulosae conferiu 92,6\% de proteção quando os suínos foram desafiados com ovos de Taenia solium. Quatro de cinco animais imunizados com 1000 mg de plasmídio recombinante e desafiados não apresentaram cistos viáveis de cisticercose. Entretanto, a imunização com $200 \mathrm{mg}$ de plasmidio recombinante não foi capaz de impedir a formação de cistos viáveis (GUO et al., 2007).

Vacina de DNA contra a anaplasmose bovina tem sido investigada com diferentes proteínas de superfície (MSPs). O gene (mspla) que codifica MSP1a do Anaplasma marginale foi inserido no plasmídio pVCL, vetor de células de mamíferos. A soroconversão, após a inoculação de camundongos e de bovinos com o DNA plasmidial contendo o gene mspla, foi demonstrada após 21 dias e seis a oito semanas, respectivamente. Em bovinos a produção de imunoglobulina foi restrita ao isotipo IgG1, embora a estimulação de linfócito $\mathrm{T}$ auxiliar também foi verificada com a produção de IFN-g (ARULKANTHAN et al., 1999). A imunização de bovinos utilizando apenas o gene que codifica a MSP1b em plasmídio de expressão para células de mamíferos (pcDNA3.1./msp1b), não estimulou satisfatoriamente a produção de anticorpos no período de vacinação, mostrando a necessidade de mais estudos para o desenvolvimento de uma vacina de 
DNA para o controle da anaplasmose (ANDRADE et al., 2004). A eficácia de uma vacina de DNA expressando 2 fatores de crescimento hemopoiético, a tirosina kinase 3 e o fator estimulante de macrófago, foi avaliada, demonstrando que estes fatores aumentam o número de células dendrídicas no sítio de imunização e aumenta a resposta das células CD4+ para MSP1a de A. marginale (MWANGI et al., 2002). A vacina para anaplasmose incorporando a proteína VP22 do BoHV-1 demonstrou a habilidade desta proteína melhorar a expressão da MSP1a de A. marginale pelas células dendríticas e macrófagos, o que sugere uma melhora na propagação da vacina de DNA para as células T CD4+(MWANGI et al., 2005).

\section{Segurança Biológica}

As pesquisas têm focado na construção funcional das vacinas de DNA, portanto, a ênfase na segurança tem sido limitada. Os elementos genéticos e as características do hospedeiro relacionado à biossegurança das vacinas de DNA foram discutidos por GLENTING \& WESSELS (2005). A tendência da construção das vacinas é a utilização de vetores isentos de genes virais, substituição de genes de resistência aos antimicrobianos por genes sintéticos e mutações para seleção de clones.

Os procedimentos associados à construção da vacina, a avaliação pré-clínica e os ensaios clínicos para estas vacinas são similares ao outros produtos biológicos. Em função do limitado conhecimento científico sobre a segurança biológica das vacinas de DNA, os estudos pré-clínicos devem ser enfatizados para a avaliação da segurança destas vacinas antes do uso comercial.

\section{Considerações Finais}

A vacinação com DNA é uma tecnologia promissora na prevenção e controle de doenças em medicina humana e veterinária. Fatores como o tipo de vetor (promotor) e da localização do plasmídio, dose e tipo do antígeno, via de administração, formulação da vacina, presença ou ausência de seqüências imunoestimulatórias, presença de plasmídio adicional ou na forma de vacina de DNA multivalente, influenciam no desenvolvimento do tipo de resposta imune. Estes fatores podem ser otimizados para melhorar a resposta imune no modelo de espécie animal para cada doença.

\section{Referências}

ANDRADE, G. M.; MACHADO, R. Z.; VIDOTTO, M.C.; VIDOTTO, O. Immunization of bovines using a DNA vaccine (pcDNA3.1/MSP1b) prepared from the Jaboticabal strain of Anaplasma marginale. Annals of the New York Academy of Sciences, New York, v.1026, p.257-266, 2004.

ANDREW, M.C.; MORRISSY, C. J.; LENGHAUS, C.; OKE, P. G.; SPROAT, K. W.; HODGSON, A. L. M.; JOHNSON, M. A.; COUPER, B. E. H. Protection of pigs against classical swine fever with DNA delivered gp55. Vaccine, Kidlinton, v.18, p.1932-1938, 2000.

ARRODE, G.; HEDGE, R.; MANI, A.; JUN, Y.; CHEBLOUNE, Y.; NARAYAN, O. Phenotypic and functional analysis of immune CD8+ T cell responses induced by a single injection of a HIV DNA vaccine in mice. The Journal Immunology, Baltimore, v.178, n.4, p.2318-2327, 2007.

ARULKANTHAN, A.; BROWN, W. C.; MCGUIRE, T. C.; KNOWLES, D. P. Biased immunoglobulin G1 isotype responses induced in cattle with DNA expressing mspla of Anaplasma marginale. Infection and Immunity, Washington, v.67, n.7, p.3481-3487, 1999.

AZEVEDO, V.; LEVITUS, G.; MIYOSHI, A.; CÂNDIDO, A. L.; GÓES, A. M.; OLIVEIRA, S. C. Main features of DNAbased immunization vectores. Brazilian Journal of Medical and Biology Research, Ribeirão Preto, v.32, n.2, p.147-153, 1999.

BINS, A. D.; JORRITSMA, A.; WOLKERS, M. C.; HUNG, C. F.; WU, T. C.; SCHUMACHER, T. N.; HAANEN, J. B. Rapid and potent DNA vaccination strategy defined by in vivo monitoring of antigen expression. Nature Medicine, New York, v.11, n.8, p.899-904, 2005.

BLOOM, B. R. New approaches to vaccine development. Reviews of Infectious Diseases, Chicago, v.11, p.460-466, 1989.

BOYLE, J. S., BRADY, J. L., LEW, A. M. Enhanced responses to a DNA vaccine encoding a fusion antigen that is directed to sites of immune induction. Nature, London, v.392, p.408-411, 1998. 
BRANGER, C.; CHATRENET, B.; GAUVRIT, A.; AVIAT, F.; AUBERT, A.; BACH, J. M.; ANDRE-FONTAINE, G. Protection against Leptospira interrogans Sensu Lato Challenge by DNA Immunization with the Gene Encoding Hemolysin-Associated Protein 1. Infection and Immunity, Washington, v.73, n.7, p.4062-4069, 2005.

BRIANE, D., LESAGE, D., CAO, A., COUDERT, R., LIEVRE, N., SALZMANN, J. L., TAILLANDIER, E. Cellular pathway of plasmids vectorized by cholesterol-based cationic liposomes. The Journal of Histochemistry \& Cytochemistry, Washington, v.50, n.7, 983-991, 2002.

CHAMBERS, M. A., VORDERMEIER, H. M., WHELAN, A., COMMANDER, N., TASCON, R., LOWRIE, D., HEWINSON, R. G. Vaccination of mice and cattle with Plasmid DNA Encoding the Mycobacterium bovis Antigen MPB83. Clinical Infectious Diseases, Chicago, v.30, p.S283-S287, 2000.

COBAN, C., ISHII, K. J., GURSEL, M., KLINMAN, D. M., KUMAR, N. Effect of plasmid backbone modification by different human $\mathrm{CpG}$ motifs on the immunogenicity of DNA vaccine vectors. Journal of Leukocyte Biology, Bethesda, v.78, n.5, p.647-655, 2005.

CONG, H., GU, Q. M., ZHOU, H. Y., GUO, L., YANG, T. L., HE, S. Y., LI, Y., ZHAO, Q. L. Oral mixed DNA vaccine protects mice from infection of Toxoplasma gondii. Zhongguo Ji Sheng Chong Xue Yu Ji Sheng Chong Bing ZaZhi, v.23, n.3, p.159-162, 2005.

COUTELIER, J. P.; VAN DER LOGT, J. T. M.; HEENSSEN, F. W. A. IgG subclass distribution of primary and secondary immune responses concomitant with viral infection. Journal of Immunology, Bethesda, v.147, n.4, p.1383-1386, 1991.

DAVIS, H. L., MCCLUSKIE, M. J. DNA vaccines for viral diseases. Microbes Infection, Berlin, v.1, n.1, p.7-21, 1999.

DOOLAN, D. L., HOFFMAN, S. L. Multi-gene vaccination against malaria: a multistage, multi-immune response approach. Parasitology Today, California, v.13, n.5, p.171178, 1997.

DUFOUR, V. DNA vaccines: new applications for veterinary medicine. Veterinary Sciences Tomorrow, Utrecht, v.2, n.1, p.1-25, 2001.

EPSTEIN, J. E.; CHAROENVIT, Y.; KERSTERB, K. E.; WANG, R.; NEWCOMER, R.; FITZPATRICK, S.; RICHIE, T. L.; TORNIEPORTH, N.; HEPPNER, D. G.; OCKENHOUSE, C.; MAJAM, V.; HOLLAND, C.; ABOT, E.; GANESHAN, H.; BERZINS, M.; JONES, T.; FREYDBERG, C. N.; NG, J.; NORMAN, J.; CARUCCI, D. J.; COHEN, J.; HOFFMAN, S. L. Safety, tolerability, and antibody responses in humans after sequential immunization with PfCSP DNA vaccine followed by the recombinant protein vaccine RTS,S/AS02A. Vaccine, Kidlinton, v.22, p.1592-1603, 2004.

FULLER, D. H.; LOUDON, P.; SCHMALJOHN, C. Preclinical and clinal progress of particle-mediated DNA vaccines for infection diseases. Methods, Minnesota, p.8697, 2006.

FYAN, F. F; WEBSTER, R. G.; FULLER, D. H.; HAYNES, J. R.; SANTORO, J. C.; ROBINSON, H. L. DNA vaccines: protective immunizations by parenteral, mucosal, and genegun inoculations. Proceedings of the National Academy of Sciences of the United States of America, Washington, v.90, n.42, p.11478-11482, 1993.

GARMONY, H. S.; BROWN, K. A.; TITBALL, R. W. DNA vaccines: improving expression of antigens. Genetic Vaccines and Therapy, Flórida, v.1, n.2, p.2-5, 2003.

GLENTING, J., WESSELS, S. Ensuring safety of DNA vaccines. Microbial Cell Factories, Barcelona, v.4, n.26, p.1-5, 2005 .

GUO, A.; JIN, Z.; ZHENG, Y.; HAI, G.; YUAN, G.; LI, H.; $\mathrm{CAI}, \mathrm{X}$. Induction of protection against porcine cysticercosis in growing pigs by DNA vaccination. Vaccine, Kidlinton, v.25, p.170-175, 2007.

GURUNATHAN, S.; KLINMAN, D. M.; SEDER, R. A. DNA vaccines: immunology, applications, and optimization. Annual Review of Immunology, California, v.18, p.927-974, 2000.

HAN, R.; CLADEL, N. M.; REED, C. A.; PENG, X.; CHRISTENSEN, N. D. Protection of rabbits from viral challenge by gene gun-based intracutaneous vaccination with a combination of cottontail rabbit papillomavirus E1, E2, E6, and E7 genes. Journal of Virology, Princeton, v.73, n.8, p.7039-7043, 1999.

HENKE, A. DNA immunization - a new chance in vaccine research? Medical microbiology and immunology, Berlin, v.191, p.187-190, 2002.

HERMANSON, G. A cationic lipid-formulated plasmid DNA vaccine conferes antibody-mediated protective against aerosolized anthrax spores. Proceedings of the National Academy of Sciences of the United States of America, Washington, v.101, n.37, p.13601-13606, 2004.

JIN, H.; LI, Y.; MA, Z.; ZHANG, F.; XIE, Q.; GUD, D.; WANG, BIN. Effect of chemical adjuvants on DNA vaccination. Vaccine, Kidlinton, v.22, p.2925-2935, 2004.

KALINNA, B.H. DNA vaccines for parasitc infections. Immunology and Cell Biology, Camberra, v.75, p.370-375, 1997.

KAUR R.; RAUTHAN M.; VRATI S. Immunogenicity in mice of a cationic microparticle-absorbed plasmid DNA encoding Japanese encephalitis virus envelope protein. Vaccine, Kidlinton, v.22, p.2776-2782, 2004. 
KIM, T. W.; HUNG, C. F.; ZHENG, M.; BOYD, D. A.; HE, L.; PAI, S. I.; WU, T. C. A DNA vecine co-expressing antigen and an anti-apoptotic molecule further enhances the antigen specific $\mathrm{CD} 8^{+} \mathrm{T}$ cell immune response. Journal of Biomedical Science, Basel, v.11, p.493-499, 2004.

KOWALCZYK, D. W.; ERTL, H. C. Immune response to DNA vaccine. Cellular and Molecular Life Sciences, Paris, v.55, p.751-701, 1999 .

KUTZLER, M. A.; ROBINSON, T. M.; CHATTERGOON, M. A.; CHOO, D. K.; CHOO, A.Y.; CHOE, P. Y.; RAMANATHAN, M. P.; PARKINSON, R.; KUDCHODKAR, S.; TAMURA, Y.; SIDHU, M.; ROOPCHAND, V.; JOSEPH KIM, J.; PAVLAKIS, G. N.; FELBER, B. K.; WALDMANN, T.; BOYER, J.D.; WEINER, D. B. Coimmunization with an optimized IL-15 plasmid resultas in enhanced function and longevity of CD8 T cells that are partially independent of CD4 T cell help. The Journal of Immunology, Bethesda, v.175, p.112-123, 2005.

LATOUCHE, J. B.; SADELAIN, M. Induction of human cytotoxic $\mathrm{T}$ lymphocytes by artificial antigen-presenting cells. Nature Biotechnology, New York, v.18, n.4, p.40540, 2000 .

LEVY, M. Y.; BARRON, L. G.; MEYER, K. B.; SZOKA, F.C. Characterization of plasmid DNA transfer into mouse skeletal muscle: evaluation of uptake mechanism, expression and secretion of gene products into the blood. Gene Therapy, Pittisburgh, v.3, p.201-211, 1996.

LEWIS, P. J.; DRUNEN LITTLE-van den HURK, S.; BABIUK, L. A. Altering the cellular location of an antigen expressed by a DNA-based vaccine modulates the immune response. Journal of Virology, Princeton, v.73, n.12, p.10214-10223, 1999.

LI, L.; FANG, W.; LI, J.; HUANG, Y.; YU, L. Oral DNA vaccination with the polyprotein gene of infectious bursal disease virus (IBDV) delivered by the attenuated Salmonella elicits protective immune responses in chickens. Vaccine, Kidlinton, v.24, n.33-34, p.5919-5927, 2006.

LIAO, J. C. F.; GREGOR, P.; WOLCHOK, J. D.; ORLANDI, F.; CRAFT, D.; LEUNG, C.; HOUGHTON, A.N.; BERGAMAN, P. J. Vaccination with human tyrosinase DNA induces antibodies responses in dogs with advanced melanoma. Cancer Immunity, New York, v.6, n.8, p.2-10, 2006.

LIMA K. M.; BONATO, V. L.; FACCIOLI, L. H.; BRANDAO, I.T.; SANTOS, S. A.; COELHO-CASTELO, A. A. Comparison of different delivery systems of vaccination for the induction of protection against tuberculosis in mice. Vaccine, Kidlinton, v.19, p.25-26, 2001.
LIMA, K. M.; SANTOS, S. A.; RODRIGUES JR., J. M.; SILVA, C. L. Vaccine adjuvant: it makes the difference. Vaccine, Kidlinton, v.22, p.2374-2379, 2004.

LIU, M.; ACRES, B.; BALLOUL, J. M.; BIZOUARNE, N.; PAUL, S.; SLOS, F.; SQUIBAN, P. Gene-based vaccines and immunotherapeutics. Proceedings of the National Academy of Sciences of the United States of America, Washington, v.101, n.2, p.14567-14571, 2004.

LODMELL, D. L.; RAY, N. B.; PARNELL, M. J.; EWALT, L. C.; HANLON, C. A.; SHADDOCK, D. S.; SANDERLIN, D. S.; RUPPRECHT, C. E. DNA immunization protects nonhuman primates against rabies virus. Nature Medicine, New York, v.4, n.8, p.949-952, 1998.

MacGREGOR, R. R.; GINSBERG, R.; UGEN, K.E.; BAINE, Y.; KANG, C. U.; TU, X. M.; HIGGINS, T.; WEINER, D. B.; BOYER, J. D. T-cell responses induced in normal volunteers immunized with a DNA-based vaccine containing HIV-1 env and rev. AIDS, São Francisco, v.16, p.2137-2143, 2002 .

MACKLIN, M. D.; McCABE, D.; McGREGOR, M. W.; NEUMANN, V.; MEYER, T.; CALLAN, R.; HINSHAW, V. S.; SAWAIN, W. T. Immunization of pigs with a particlemediated DNA vaccine to influenza A virus protects against challenge with homologous virus. The Journal of Virology, Princeton, v.72, p.1491-1496, 1998.

MOREL, P. A.; FALKNER, D.; PLOWEY, J.; LARREGINA, A. T.; FALO JR., L. D. DNA immunization: altering the cellular localization of expressed protein and the immunization route allows manipulation of the immune response. Vaccine, Kidlinton, v.22, p.447-456, 2004.

MUMPER, R. J.; LEDEBUR JR, H. C. Dendritic cell delivery of plasmid DNA. Applications for controlled genetic immunization. Molecular Biotechnology, New Jersey, v.19, n.1, p.79-95, 2001.

MUÑOZ-MONTESINE, C.; ANDREWS, E.; RIVERS, R.; GONZÁLEZ-SMITH, A.; MORAGA-CID, G.; FOLCH, H.; CÉSPEDES, S.; OÑATE, A. A. Intraspleen delivery of a DNA vaccine coding for superoxide dismutase (SOD) of Brucella abortus induces SOD-specific CD4+ and CD8+ $\mathrm{T}$ cells. Infection and Immunity, Washington, v.72, n.4, p.2081-2087, 2004.

MWANGI, W.; BROWN, W. C.; LEWIN, H. A.; HOWARD, C. J.; HOPE, J. C.; BASZLER, T. V.; APLAZI, P.; ABBOTT, J.; PALMER, G. H. DNA-encoded fetal liver tyrosine kinase 3 ligand and granulocyte macrophage-colony-stimulating factor increase dendritic cell recruitment to the inoculation site and enhance antigen-specific CD4+ T cell responses induced by DNA vaccination of outbred animals. The Journal of Immunology, Bethesda, v.169, n.7, p.3837-3846, 2002. 
MWANGI, W.; BROWN, W. C.; SPLITTER, G. A.; ZHUANG, Y.; KEGERREIS, K.; PALMER, G. H. Enhancement of antigen acquisition by dendritic cells and MHC class II-restricted epitope presentation to CD4+ T cells using VP22 DNA vaccine vectors that promote intercellular spreading following initial transfection. Journal of Leukocyte Biology, Cambridge, v.78, n.2, p.401411, 2005.

NAFTZGER, C.; TAKECHI, Y.; KOHDA, H.; HARA, I.; VIJAYASARADHI, S.; HOUGHTON, A. N. Immune response to a differentiation antigen induced by altered antigen a study of tumor rejection and autoimmunity. Proceedings of the National Academy of Sciences of the United States of America, Washington, v.93, p.1480914814, 1996.

NAGATA, T.; AOSHI, T.; UCHUIMA, M.; SUZUKI, M.; KOIDE, Y. Cytotoxic T-lymphocyte, and helper Tlymphocyte oriented DNA vaccination. DNA and Cell Biology, Philadelphia, v.23, n.2, p.93-106, 2004.

NAGATA, T:; UCHIJIMA, M.; YOSHIDA, A.; KAWASHIMA, M.; KOIDE, Y. Codon optimization effect on translational efficiency of DNA vaccine in mammalian cells; análisis of plasmid DNA encoding a CTL epitope derived from microrganisms. Biochemical and Biophysical Research Communications, Martinsried,v.261, p.445-451, 1999.

NORMAN, J. A.; HOBART, P.; MANTHIRPE, M.; FELGNER, P.; WHEELER, C. Development of improved vectors for DNA-based immunization and other gene therapy applications. Vaccine, Kidlinton, v.15, n.8, p.801803, 1997.

NOUR-EL-DIN, A. N.; SHKRETA, L.; TALBOT, B. G.; DIARRA, M. S.; LACASSE, P. DNA immunization of dairy cows with the clumping factor A of Staphylococcus aureus. Vaccine, Kidlinton, v.24, n.12, p.1997-2006, 2006.

OKADA, M.; KITA, Y.; NAKAJIMA, T.; KANAMARU, N.; HASHIMOTO, S.; NAGASAWA, T.; KANEDA, Y.; YOSHIDA, S.; NISHIDA, Y.; KUKAMUZU, R.; TSUNAI, Y.; INOUE, R.; NAKATANI, H.; NAMIE, Y.; YAMADA, J.; TAKAO, K.; ASAI, R.; MATSUMOTO, M.; McMURRAY, D. N.; DELA CRUZ, E. C.; TAN, E. V.; ABALOS, R. M.; BURGOS, J.;A.; GELBER, R.; SAKATANI, M. Evaluation of a novel vaccine (HVJliposome/HSP65 DNA+IL-12 DNA) against tuberculosis using the cynomolgus monkey model of TB. Vaccine, Kidlinton, v.22, p.2990-2993, 2007.

OLIVEIRA, S.C.; HARMS, J. S.; RECH, E. L.; RODART, R. S.; BOCCA, A. L.; GOES, A. M.; SPLITTER, G. A. The role of $\mathrm{T}$ cell subsets and cytokines in the regulation of an intracellulaar bacterial infection. Brazilian Journal of Medical and Biological Research, Ribeirão Preto, v.32, p.77-84, 1998.
OÑATE, A. A.; CÉSPEDES, S.; CABRERA, A.; RIVERS, R.; GONZÁLES, A.; MUÑOZ, C.; FOLCH, H.; ANDREWS, E. A DNA vaccine encoding $\mathrm{Cu}, \mathrm{Zn}$ superoxide dismutase of Brucella abortus induces protective immunity in BALB/ c mice. Infection and Immunity, Washington, v.71, n.9, p.4857-4861, 2003.

OSORIO, J. E.; TOMLINSON, C. C.; FRANK, R. S.; HAANES, E. J.; RUSHLOW, K.; HAYNES, J. R.; STINCHOMB, D. T. Immunization of dogs and cats with a DNA vaccine against rabies virus. Vaccine, Kidlinton, v.17, p.1109-1116, 1999.

OTTEN, G. R.; SCHAEFER, M.; DOE, B.; LIU, H.; MEGEDE, J.Z.; DONNELY, J.; TABUSSAY,D.; BARNETT, S.; ULMER, J. B. Potent immunogenicity of ana HIV-1 gagpol fusion DNA vaccine delivered by in viv eletroporation. Vaccine, Kidlinton, v.24, n.21, p.4503-4509, 2006.

PASQUINI, S.; XIANG, Z.; WANG, Y.; HE, Z.; DENG, H.; BLASCZYK-THURIN, M.; ERTL, H. C. J. Cytokines and costimulatory molecules as genetic adjuvant. Immunology and Cell Biology, London, v.75, p.397-401, 1997.

PERKINS, S. D.; FLICK-SMITH, H. C.; GARMONY, H. S.; ESSEX-LOPRESTI, A. E.; STEVENSON, F. K.; PHILLPOTTS, R. J. Evaluation of the VP22 protein for enhancement of a DNA vaccine against anthrax. Genetic Vaccines and Therapy, Florida, v.3, n.3, p.1-9, 2005.

RAINCZUK, A.; SMOOKER, P. M.; KEDZIERSKI, L.; BLACK, C. G.; COPPEL, R. L.; SPITHILL, T. W. The protective efficacy of MSP4/5 against lethal Plasmodium chabaudi adami challenge is dependent on the type of DNA vaccine vector and vaccination protocol. Vaccine, Kidlinton, v.21, p.3030-3042, 2003.

RAMSHAW, I. A.; FORDHAM, S. A.; BERNARD, C. A.; MAGUIRE, D.; COWDEN, W.B.; WILLENBORG, D. O. Dna vaccine for the treatment of autoimune disease. Immunology and Cell Biology, London, v.75, p.409-413, 1997.

RAZ, E.; WATANABE, A.; BAIRD, S. M.; EISENBERG, R. A.; PARR, T. B.; LOTZ, M.; KIPPS, T. J.; CARSON, D. A. Systemic immunological effects of cytokine genes injected into skeletal muscle. Proceedings of the National Academy of Sciences of the United States of America, Washington, v.90, n.10, p.4523-4527, 1993.

REN, S.; LI, M.; SMITH, J. M.; DETOLLA, L. J.; FURTH, P.A. Low-volume jet injection for intradermal immunization in rabbits. BMC Biotechnology, Maryland, v.2, n.10, p.16,2002 .

ROBINSON, H. L. Nucleic acid vaccines: an overview. Vaccine, Kidlinton, v.15, n.8, p.785-787, 1997. 
RODRIGUES JÚNIOR, J. M.; LIMA, K. M.; CASTELO, A. A. M.; MARTINS, L. D. B.; SANTOS, S. A. S.; FACCIOLI, L. H.; SILVA, C. L. É possível uma vacina gênica auxiliar no controle da tuberculose? Jornal Brasileiro de Pneumologia, Ribeirão Preto, v.30, p.468-477, 2004.

SEDEGAH, M.; CHAROENVIT, L.; BELMONTE, M.; MAJAN, V. F.; ABOT, S.; GANESHAN, H.; KUMAR, S.; BACON, D. J.; STOWERS, A.; NARUM, D. L.; CARUCCI, D. J.; ROGERS, W. O. Reduced immunogenicity of DNA vaccine plasmids in mixtures. Gene Therapy, Pittisburg, v.1, p.448-456, 2004.

SEDEGAH, M.; JONES, T. R.; KAUR, M.; HEDSTROM, R.; HOBART, P.; TINES, J. A.; HOFFMAN, S. L. Boosting with recombinant vaccinia increases immunogenicity and protective efficacy of malaria DNA vaccine. Proceedings of the National Academy of Sciences of the United States of America, Washington, v.95, p.7648-7653, 1998.

SIEGRIST, C. A. Potencial advantages and risks of nucleic acid vaccines for infant immunization. Vaccine, Kidlinton, v.15, n.8, p.798-800, 1997.

SIN, J. I.; KIM, J. J.; ARNOLD, R. L.; SHROFF, K. E.; MCCALLUS, D.; PACHUK, C.; MCELHINEY, S. P.; WOLF, M. W.; POMPA-DE BRUIN, S. J.; HIGGINS, T. J.; CICCARELLI, R. B.; WEINER, D. B. IL-12 gene as a DNA vaccine adjuvant in a herpes mouse model: IL-12 enhances Th1-type CD4(+) T cell-mediated protective immunity against herpes simplex virus-2 challenge. Journal Immunology, Bethesda, v.162, p.2912-2921, 1999.

SINGH, M., BRIONES, M.; OTT, G.; O'HAGAN, D. Cationic microparticles: a potent delivery system for DNA vaccines Proceedings of the National Academy of Sciences of the United States of America, Washington, v.97, p.811-816, 2000.

SINGH, M.; O'HAGAN, D. T. Recent advances in vaccine adjuvants. Pharmaceutical Research, Hong Kong, v.19, n.6, p.715-728, 2002.

SNADEEP, K.; TRIPATHY, S. K.; SVENSSON, E. C.; BLACK, H. B.; GOLDWASSER, E.; MARGALITH, M.; HOBART, P. M.; LEIDEN, J. M. Long-term expression of erythropoietin in the systemic circulation of mice after intramuscular injection of a plasmid DNA vector. Genectics, Pittsburgh, v.93, p.10876-10880, 1996.

SNAPPER, C. M.; FINKELMAN, F. D.; PAUL, W. E. Regulation of IgG1 and IgE production by interleukin 4. Immunological Reviews, Philadelphia, v.102, p.51-75, 1988.

SOMASUNDARAM, C.; TAKAMATSU, H.; ANDREONI, C.; AUDONNET, J. C.; FISHER, L.; LEFEVRE, F.; CHARLEY, B. Enhanced protective response and immune adjuvant effects of porcine CM-CSF on DNA vaccination of pigs against Aujeszky's disease virus. Veterinary
Immunology and Immunopathology, Massachussets, v.70, p.277-287, 1999.

UCHIJIMA, M.; YOSHIDA, A.; NAGATA, T.; KOIDE, Y. Optimization of codon usage of plasmid DNA vaccine is required for the effective $\mathrm{MHC}$ class I-restrict $\mathrm{T}$ cell responses against an intracellular bacterium. Journal Immunology, Bethesda, v.161, p.5594-5599, 1998.

ULMER, J. B.; DECK, R. R.; DEWITT, C. M.; FU, T. M.; DONNELLY, J. J.; CAULFIELD, M. J.; LIU, M. A. Expression of a viral protein by muscle cells in vivo induces protective cell-mediated immunity. Vaccine, Kidlinton, v.15, n.8, p.839-841, 1997.

ULMER, J. B.; DONNELLY, J. J.; PARKER, S. E.; PODES, G. H.; FELGNER, P. L.; DWARKI, V. J.; GROMKOWSKI, S. H.; RANDALL DECK, R.; DeWITT, C. M.; FRIEDMAN, A.; HAWE, L.A.; LEANDER, K. R.; MARTINEZ, D.; PERRY, H. C.; SHIVER, J. W.; MONTGOMERY, D. L.; LIU, M. A. Heteroulogous protection against influenza by injection of DNA encoding a viral protein. Science, New York, v.259, p.1745-1749, 1993.

ULMER, J. B.; WAHREN, B.; LIU, M. A. Gene-based vaccines: recent technical and clinical advances. TRENDS in Molecular Medicine, London, v.12, n.5, p.216-222, 2006.

VAN DRUNEN LITTEL-van den HURCK, S.; BRAUN, R. P.; KARVONEN, B. C.; KING, T.; YOO, D.; BABIUK, L. A. Immune response and ptoection induced by DNA bacines encodoing bovine parainfluenza virus type 3 glycoproetin. Virology, Illinois, v.260, p.35-46, 1999.

VAN TIENHOVEN, E. A. E.; TEN BRINK, C. T. B.; VAN BERGEN, J.; KONING, F.; VAN EDEN, W.; BROEREN, C. $\mathrm{P}$. M. Induction of antigen specific $\mathrm{CD}^{+} \mathrm{T}$ cell responses by invariant chain based DNA vaccines. Vaccine, Kidlinton, v.19, p.1515-1519, 2001.

VANROMPAY, D.; COX, E.; VANDENBUSSCHE, F.; VOLCKAERT, G.; GODDEERIS, B. Protection of turkeys against Clamydia psitaci challenge by gene gun-based DNA immunizations. Vaccine, Kidlinton, v.17, p.2628-2635, 1999.

VELIKOVSKY， C. A.; CASSATARO, J.; GIAMBARTOLOMEI, G. H.; GOLDBAUM, F. A.; ESTEIN, S.; BODWEN, R. A.; BRUNO, L.; FOSSATI, C. A.; SPITZ, M. A DNA vaccine encoding lumazine synthase from Brucella abortus induce protective immunity in BALB/c mice. Infection and Immunity, Washington, v.70, n.5, p.2507-2511, 2002.

VERCAMMEN, M.; SCORZA, T.; HUYGEN, K.; DE BRAEKELEER, J.; DIET, R.; JACOBS, D.; SAMAN, E.; VERSHUEREN, H. DNA vaccination with genes encoding toxoplasma gondiiantigens GRA1, GRA7, and ROP2 induces partially protective immunity against lethal 
challenge in mice. Infection and Immunity, Washington, v.68, n.1, p.38-45, 2000.

WAINE, G. J., McMANUS, D. P. Nucleic Acids: Vaccines of the future. Parasitology Today, Califórnia, v.11, n.3, p.113-116, 1995.

WANG, R.; DOOLAN, D. L.; LE, T. P.; HEDSTROM, R. C.; COONAN, K. M.; CHAROENVIT, Y. Induction of antigenspecific cytotoxic $\mathrm{T}$ lymphocytes in humans by malaria DNA vaccine. Science, New York, v.282, p.476-480, 1998.

WANG, S.; FARFAN-ARRIBAS, D. J.; SHEN, S.; CHOU, T.H.W.; HIRSCH, A.; HE, F.; LU, S. Relative contribuitions of códon usage, promotor efficiency and teader sequence to the antigen expression and immunogenicity of HIV-1 Env DNA vaccine. Vaccine, Kidlinton, v.24, n.21, p.45314540, 2005.

WEBER, L.W.; BOWNE, W.B.; WOLCHOK, J. D.; SRINIVASAN, R.; QIN, J; MOROI, Y.; CLYNES, R.; SONG P, L. J. J.; HOUGHTON, A. N. Tumor immunity and autoimmunity induced by immunization with homologous DNA. The Journal of Clinical Investigation, Michigan, v.102, n.6, p.1258-1264, 1998.

WHALEN, R. G. DNA vaccines for emerging infectious diseases: what if? Emerging Infectious Diseases, Atlanta, v.2, n.3, p.168-175, 1996.

WOLFF, J. A.; MALONE, R. W.; WILLIAMS, P.; CHONG, W.; ACSADI, G.; JANI, A.; FELGHER, P. L. Direct gene transfer into mouse muscle in vivo. Science, New York, v.247, p.1465-1468, 1990.
XIANG, Z. Q.; HE, Z.; QANG, Y.; ERTL, H. The effect of interferon-g on genetic immunization. Vaccine, Kidlinton, v.15, n.8, p.896-898, 1997.

XU, Z. L.; MIZUGUCHI, H.; ISHII-WATABE, A.; UCHIDA, E.; MAYUMI, T.; HAYAKAWA, T. Optimization of transcriptional regulatory elements for constructing plasmid vectors. Gene, Napoli, v.272, p.149-156, 2001.

YOSHIDA, A.; NAGATA, T.; UCHIJIMA, M.; HIGASHI, T.; KOIDE, Y. Advantage of gene gun-mediated over intramuscular inoculation of plasmid DNA vaccine in reproducible induction of specific immune responses. Vaccine, Kidlinton, v.18, p.1725-1729, 2000.

ZHANG, X.; DIVANGAHI, M.; NGAI, P.; SANTOSUOSSO, M.; MILLAR, J.;ZGANIAZ, A.; WANG, J.; BRAMSON, J.; XING, Z. Intramuscular immunization with a monogenic plasmid DNA tuberculosis vaccine: Enhanced immunogenicity by electroporation and co-expression of GM-CSF transgene. Vaccine, Kidlinton, v.25, n.7, p.13421352, 2007.

ZHENG, C.; BABIUK,L. A.; VANDRUNEMLITTLE-VAN DEN HURK, S. Bovine Herpesvirus 1 VP22 enhances the efficacy of DNA vaccine in cattle. Journal of Virology, Princeton, v.79. n.3, p.1948-1953, 2005.

ZHOU, H.; DNA-based vaccines activate innate and adaptive antitumor immunity by engaging the NKG2D receptor. Proceedings of the National Academy of Sciences of the United States of America, Washington, v.102, n.31, p.10846-10851, 2005. 